\title{
The Structure of the Concept of Political Freedom in Hannah Arendt's Philosophy ${ }^{1}$
}

\author{
Katarzyna Eliasz \\ Jagiellonian Univesity, Cracow, Poland \\ katarzyna.eliasz@uj.edu.pl \\ Received 5 September 2018; accepted 29 December 2018; published 30 April 2019.
}

\begin{abstract}
This paper is devoted to clarifying Hannah Arendt's concept of political freedom (which, at certain points, is markedly obscure) by the means of analysing its structure. My analysis proceeds in three steps. Firstly, I distinguish a pre-political concept of freedom as exercising spontaneity, which is at the root of Arendt's understanding of political freedom. Secondly, I analyse her account of freedom as exercising action and indicate its relationship to the elementary freedom of spontaneity. Arendt endowed action with a distinguished importance, since she assumed that it is the only activity within the vita activa (the other two being labour and work), which has a special anthropological and axiological significance. According to Arendt, only action allows one to truly experience the fundamental aspect of the human condition, which is the fact of human plurality; it is also the only activity which allows one to exercise specifically public principles, such as solidarity, equality, or justice. Thirdly, I indicate how these two accounts of freedom translate into Arendt's concept of political freedom. This analysis reveals that the Arendtian concept of political freedom is markedly original. She did not define it in a usual manner, i.e. through indicating bundles of legal and political rights which determine the accepted scope of participation in the public affairs. The inherent part of her concept of political freedom is a specific account of how it must be exercised (i.e. through action). Political freedom understood as the participation in governance exercised through action is not merely an activity of instrumental, but also anthropological and axiological importance, which is due to the special anthropological and axiological meaning of action. In the final section, I discuss the practical dimension of Arendt's theory. She doubted whether the traditional representative democracy is capable of accommodating her 'rich'
\end{abstract}

\footnotetext{
${ }^{1}$ The following article was prepared as part of the research grant "The Place of Political Freedom in the Hierarchy of Democratic Values", founded by the National Science Centre, Poland, on the basis of the decision DEC2016/23/D/HS5/01814.
} 
ideal of political freedom, therefore she proposed an alternative account of political system based on councils. I formulate objections against this proposition and demonstrate that councils would presumably fail to accommodate Arendt's exacting account of political freedom.

Keywords: Hannah Arendt; political freedom; public action; spontaneity; councils; representative democracy.

\section{Introduction}

The reading of Hannah Arendt's brilliant works is sometimes obscured by ambiguities in her conceptual scheme. One of the most apparent ones concerns the meaning of political freedom. In this paper, I attempt to clarify this concept by analysing its structure. I begin my analysis with distinguishing a rudimentary, pre-political account of freedom, which she labeled as spontaneity. This rudimentary concept of freedom is at the basis of Arendt's concept of political freedom (it is the fundament of its structure). The next level of this structure involves freedom understood as exercising action (the most momentous activity within the hierarchy of vita activa), which is connected with the previous one in that spontaneity finds its upmost realisation in it. Thus, acting implies being free by virtue of exercising spontaneity, but it possesses yet another dimension of freedom. Now, Arendt's account of political freedom is built upon the traditional concept thereof, which embraces a set of political rights (especially the right to participate in governance) and, additionally, requires that these rights be exercised in a specific way, namely through action (and, therefore, spontaneously). As this brief summary indicates, the objective of this paper can be captured in both analytical and practical terms, since political freedom as a means of participating in government is inherently connected to the question of the political order.

The exposition of Arendt's views presented in this paper may arouse objections, since on many occasions she seemed to imply that only political freedom is the freedom par excellence (cf. Arendt, 2006a, p. 147). Therefore, a clarificatory remark is in order before I proceed to the next section. As I already mentioned, political freedom from Arendt's perspective is a complex concept: it encompasses two pre-political kinds of freedom (spontaneity and exercising action). My aim is to reveal that political freedom derives its special significance precisely from these two varieties of freedom and that Arendt's appreciation of political vita activa draws on her particular philosophical and anthropological assumptions.

\section{Freedom as Spontaneity}

I shall begin my analysis with distinguishing the first, rudimentary meaning of freedom in Arendt's philosophy. As I already mentioned, she assumed that it is tantamount to acts of spontaneity, i.e. initiating new and unexpected events (cf. Arendt, 2005b, p. 113). Arendt admitted that this understanding of freedom is of Augustinian origin, yet her debt to Augustine is by no means obvious. Augustine discussed freedom explicitly in relation to inner disposition of liberum arbitrium, yet Arendt insisted that the final passages of Book XII 
Chapter 20 of The City of God contain the second, less obvious account of freedom (cf. Arendt, 2006a, pp. 165-166). In these passages, Augustine refutes the doctrine of cyclic time by indicating that it contradicts God's capacity to introduce novelty and human ability to initiate new chains of events (cf. Arendt, 1996, p. 55). Augustine concludes with the following remark (which Arendt cited on numerous occasions): "In order that there might be this beginning, therefore, a man was created before whom no man existed" (Augustine, 2002, p. 532). It is worth repeating that Augustine did not identify a capacity to initiate with freedom, though, in Arendt's view, he would have done so had he drawn final conclusions from his investigations; as she wrote:

If Augustine had drawn the consequences of these speculations, he would have defined men, not, like the Greeks, as 'mortals', but as 'natals', and he would have defined the freedom of the Will not as the liberum arbitrium, the free choice between willing and nilling, but as the freedom of which Kant speaks in the Critique of Pure Reason. (i.e. as spontaneity; Arendt, 1978, p. 109)

What is particularly important in Arendt's interpretation of Augustine is that freedom is no longer perceived only as inner experience or an internal disposition, but as an inherent aspect of human existence in the world (cf. Arendt, 2006a, p. 165). ${ }^{2}$

As far as the origins of this freedom are concerned, Arendt asserted that human beings acquire it by mere fact of coming to the world, which she called 'natality' and characterised in the following manner:

In the birth of each man this initial beginning is reaffirmed, because in each instance something new comes into an already existing world which will continue to exist after each individual's death. Because he is a beginning, man can begin; to be human and to be free are one and the same. God created man in order to introduce into the world the faculty of beginning: freedom. (Arendt, 2006a, p. 166)

Arendt's claim that spontaneity springs from the mere fact of being born is markedly obscure. It is unclear how the fact of being born (the human condition of natality) translates into a capacity to begin something new and unexpected. This objection, however, is rather inessential, especially if we take into account the depth at which she analyses it phenomenologically. Her analysis involves many perceptive observations, which I shall try to encapsulate in three theses.

\footnotetext{
${ }^{2}$ Arendt's account of freedom as initiating new and unexpected events makes one ponder the significance of will in exercising it. Therefore, explanatory remarks are in order. Arendt never questioned the existence of the faculty of will, for which she provided a phenomenological argument, i.e. she assumed that the internal experience of willing is sufficient to prove its existence (c.f. Arendt, 1978, p. 5). She defined free will as a mental faculty which commands the execution of aims indicated by judgment, i.e. it is the faculty which dictates our activities (Arendt, 2006a, p. 150). In other words, Arendt perceived will as the power to initiate new events (Arendt, 1978, p. 6). Thus, according to her, exercising will is understood not in terms of a question of freedom, but in terms of the internal strength or weakness (c.f. Arendt, 2006a, p. 150).
} 


\subsection{Thesis 1: Spontaneity implies that man is born for freedom, as opposed to being born free (cf. Kohn, 2000, p. 115)}

This thesis might seem inconsistent with what has been written above about spontaneity as the consequence of natality, yet a closer reading of Arendt's considerations reveals that she treats spontaneity not only as a fact (she wrote: "We are doomed to be free by virtue of being born, no matter whether we like freedom or abhor its arbitrariness" [Arendt, 1978, p. 217]), but also as a value that is essential to the fully human life. Since spontaneity is also a value, it can be realised to a greater or lesser extent. Arendt assumes that we can refrain, or - on extremely rare occasions that I will briefly discuss further-be deprived of the possibility to exercise spontaneity, though we can never lose a capacity for it. It must be stressed that it is almost impossible not to exercise it at all. The fact that we almost always exercise spontaneity in some way stems from Arendt's markedly broad understanding thereof: it does not amount merely to extraordinary deeds, but includes ordinary but non-schematic initiatives realised in various activities. In the course of her analyses, Arendt described only one extraordinary circumstance in which spontaneity is almost utterly destroyed. In the study on totalitarianism, she indicated that spontaneity is annihilated through the destruction of moral and juridical-political person in a human being (cf. Arendt, 1958, p. 455). Moral destruction occurs when one is faced with circumstances whereby one is deprived of the capacity to exercise one's conscience (cf. Arendt, 1958, pp. 452-455). Annihilation of juridical-political person is tantamount to depriving a person of protection through the exclusion from legal-political community (cf. Arendt, 1958, p. 447). These two mechanisms (applied to the greatest extent in concentration camps) destroy human individuality and, thereby, spontaneity, "For to destroy individuality is to destroy spontaneity, man's power to begin something new out of his own resources" (Arendt, 1958, p. 455). Now, Arendt's examples of the circumstances in which spontaneity is annihilated are, in fact, situations when human being is deprived of their humanity. Therefore, Arendt seems to imply that one cannot deliberately refrain from spontaneity and remain human.

\subsection{Thesis 2: The concept of freedom as spontaneity is neither negative nor positive}

Spontaneity should not be interpreted as a variety of negative freedom, i.e. as a capacity to act unconstrained by others (cf. Berlin, 2000, p. 194). Charles Taylor aptly characterised negative freedom as 'opportunity-concept' whereby "being free is a matter of what we can do, of what is open to us to do, whether or not we do anything to exercise these options" (Taylor, 1985, p. 213). Arendt's conception does not fit in with this description, since she assumed that freedom is a matter of actually exercising our faculty of spontaneity. It would not be right, however, to associate Arendt's idea with what Berlin labeled as positive and Taylor as 'exercise-concepts' of freedom. Exercise or positive concepts assume that the essence of freedom amounts to effective self-determination, i.e. being subject to ones' own (individual or collective) will (cf. Taylor, 1985, p. 213; Berlin, 2000, p. 203). Arguably, exercising spontaneity could result in self-determination, yet it certainly is not what this 
kind of freedom is about. For instance, one can exercise spontaneity without self-determination through engaging in artistic performance or producing a work of art.

\subsection{Thesis 3: The freedom of spontaneity is a pre-political condition of political freedom.}

As I already mentioned in the introduction, Arendt perceived spontaneity as the essential component of her concept of political freedom. As she wrote:

Although all political freedom would forfeit its best and deepest meaning without this freedom of spontaneity, the latter is itself prepolitical, as it were; spontaneity depends on organizational forms of communal life only to the extent that it is ultimately the world that can organize it (Arendt, 2005b, pp. 127-128)

In other words, freedom of spontaneity does not need politics, but political freedom that is deprived of spontaneity loses its essence. Spontaneity can manifest itself regardless of any institutional arrangements; one could enjoy it in many varieties of political systems (provided that they do not destroy human individuality). But unspontaneous (routine) political activities do not realise political freedom in the Arendtian sense. This assumption leads Arendt to maintain that political freedom requires a specific kind of activity, i.e. an activity capable of accommodating human spontaneity. She argued that within the hierarchy of vita activa (embracing two other activities, namely labour and work), action realised the value of spontaneity to the greatest extent; she defined action as the spontaneous activity par excellence. In the next section of this paper, I shall try to highlight Arendt's arguments regarding this conviction.

\section{Freedom as Action}

As was already mentioned, Arendt insisted that other activities accommodated merely an element of spontaneity, whereas action is the spontaneous activity; therefore, to grasp the essence of her argument, one should carefully discriminate action from activities such as labour and work. The arguments she presents for this claim can be reconstructed in the following way.

\subsection{Argument 1: Non-routine character of action}

It seems that this claim about action being the spontaneous activity par excellence results to a large extent from Arendt's assumption that labour and work (as opposed to action) are schematic. Labour is dictated by a biological necessity to keep oneself alive through making a living or producing goods for consumption (cf. Canovan, 1992, pp. 122-127; Arendt, 1998, pp. 7-8). Work, in turn, which amounts to creating durable artefacts, is dictated primarily by considerations of utility (cf. Arendt, 1998, p. 153). It certainly allows for more initiative than labour, since creating objects, be it either everyday objects or true 
works of art, requires creative thinking, at least to a certain extent. However, the process of work occurs when artists or craftsmen begin to reify their ideas, i.e. rework the given natural material (cf. Parekh, 1981, pp. 111-112). Such reification requires realising a preconceived model, be it a blueprint or a mental image (cf. Arendt, 1998, p. 140). In other words: "What guides the work of fabrication is outside the fabricator and precedes the actual work process in much the same way as the urgencies of the life process within the laborer precede the actual labor process" (Arendt, 1998, pp. 140-141). Therefore, both activities are schematic insofar as they are directed at achieving preconceived goals. Arguably, each of them relies on a certain scope of initiative, e.g. a factory worker could come up with a new method of doing their job, or a craftsman could design a chair shaped in an unconventional way, yet these initiatives are significant by virtue of their usefulness for achieving a concrete goal. Action, by contrast, "is not forced upon us by necessity, like labor, and it is not prompted by utility, like work" (Arendt, 1998, p. 177). Margaret Canovan characterised action concisely as a broad category involving non-schematic interactions with other people, which requires a personal initiative (cf. Canovan, 1992, p. 131). A requirement of interaction is yet another aspect of action distinguishing it from labour and work, where human relationships are not essential and of secondary importance (i.e. they may be significant insofar as they contribute to achieving specific goals of labour and work). ${ }^{3}$ It seems that action understood this way provides for different activities, such as, for instance, setting up an amateur musical ensemble or organising a protest against deforestation. It appears that the absence of clear criteria enabling to qualitatively distinguish between various types of action is an important deficiency of Arendt's theory. Yet, this problem is inessential, since presenting an exhaustive taxonomy of human activities was not Arendt's intention. As Bhikhu Parekh rightly indicates, she intended to highlight structures of the examined activities and, for that reason, focused only on its most clear and developed forms (cf. Parekh, 1981, p. 109). Thus, while writing about action, Arendt focused only on its public-political variant, which involves a specific requirement pertaining to its motivation. She assumed that action (in order to deserve its name) must be publicspirited, i.e. motivated by the concern for the common world. Therefore, activities such as setting up a musical ensemble, undertaken for the sake of private satisfaction, do not meet the conditions of action. In this light, let us bear in mind that action in the Arendtian sense is always public/political.

Before proceeding to Argument 2, let me highlight here, by way of an important digression, another (alongside spontaneity) distinctive feature of action, which is connected with its 'interactive' character. Namely, action is expressive of 'plurality' (the essential feature of the human condition) and, thereby, is public. Action's affinity with the human condition

\footnotetext{
${ }^{3}$ In labour, "man is neither together with the world nor with other people, but alone with his body, facing the naked necessity to keep himself alive" (Arendt, 1998, p. 212). Certain kinds of labour require merely presence, as opposed to committed relations with others. Work, in Arendt's view, is a more social activity. Certainly, the process of fabrication is solitary, yet its aim, i.e. market exchange, requires contact with other people. However, since the reason behind market relations is the exchange of goods, they involve 'thin' relationships, i.e. ones that are mediated by products (cf. Arendt, 1998, pp. 160-161).
} 
of plurality is a strong argument supporting Arendt's claim about its distinguished position within the hierarchy of vita activa (in addition to the previously discussed argument, according to which action is distinguished by virtue of spontaneity). Plurality amounts to the fact that human beings are both equal and distinct (cf. Arendt, 1998, pp. 175-176). Now, Arendt is adamant that experiencing plurality is crucial to a truly human life, for which she provides a twofold justification. Firstly, people need interactions with others to reveal who they are, i.e. disclose their identity (cf. Arendt, 1998, p. 208). Secondly, these interactions have an epistemological value. They allow one to recognise the world in its objectivity, since "no one can adequately grasp the objective world in its full reality all on his own, because the world always shows and reveals itself to him from only one perspective" (Arendt, 2005b, p. 128). Accordingly, through experiencing plurality in action one is prompted to perceive the world from multiple perspectives rather than through the prism of one's own particular interests. This takes us back to the previous argument, i.e. the experience of action and, thereby, of plurality liberates human beings from considerations of necessity and utility, and, thus, motivates non-schematic (spontaneous) behaviour.

As has been demonstrated, action and plurality are interrelated. Action is expressive of plurality (since it is the only activity which relies on interactions) and, without plurality, action would lose its raison d'être; it would be "a capricious interference with general laws of behavior, if men were endlessly reproducible repetitions of the same model" (Arendt, 1998, p. 8). The human condition of plurality, along with its essential component, namely the capacity for speech ("speechless action would no longer be action" [Arendt, 1998, p. 178]), enables the creation of the public sphere between people. 'The public' has a specific meaning and should not be confused with the political realm. ${ }^{4}$ While the latter sphere requires a formal institutional basis, the former one is informal and ephemeral, i.e. it emerges when people gather together to undertake a common action, and ceases to exist when they disperse. In effect, the public realm thus understood could emerge even in nondemocratic states, e.g. in "a private dining room in which people gather together to hear a Samizdat or in which dissidents meet with foreigners" (Benhabib, 1997, p. 4). Moreover, Arendt's emphasis on the fact of human plurality justifies the conclusion that the public sphere should be inclusive and expressive of social difference (cf. Young, 2000, p. 111).

\subsection{Argument 2: Action is guided by principles and hence disinterested}

As I demonstrated in the Argument 1, Arendt assumed that the spontaneity of action results from its non-routine character. To further emphasise this trait, she claimed that action is free to the extent to which it transcends considerations of particular, individual interests

\footnotetext{
${ }^{4}$ Arendt uses the term 'public' in two markedly different contexts. Sometimes, the public realm is an informal sphere of action, as opposed to the political realm that requires a formal constitution and spatial dimension (cf. Arendt, 2005b, pp. 122-123). On other occasions, she contrasts the public realm, by which she means a formally constituted sphere, with what she calls 'the space of appearance' that emerges whenever people undertake a common action (cf. Arendt, 1998, p. 199). For the sake of clarity, I use the term 'public realm' to describe the informal sphere of action, and 'political realm' to describe a formally established sphere of political institutions.
} 
(striving for which, ex hypothesi, constrains spontaneity). Therefore, according to her, action is free as long as it is guided by what she called the principles of action, as opposed to its particular goals. Arendt understood the 'principles of action' as "the fundamental convictions that a group of people share" (Arendt, 2005b, p. 195) and "the guiding criteria by which all actions in the public realm are judged beyond the merely negative yardstick of lawfulness, and which inspire the actions of both rulers and ruled" (Arendt, 2005a, p. 65). Simply put, principles are political ideals, which should not be equated with any substantive vision of the common good. They encompass, for instance, love of liberty, equality, justice, striving for distinction, or excellence (cf. Arendt, 2006a, p. 151). These principles should be distinguished from psychological motives and intellectual judgments. Unlike subjective motives, principles are universal and, unlike intellectual judgments, which recognise aims of action and devise adequate means to achieve them, they do not lose their validity upon the accomplishment of these aims (cf. Arendt, 2006a, pp. 150-151). Arendt described the relationship between freedom through action and the principles in the following manner:

Freedom $[\ldots]$ appears in the world whenever such principles are actualized; the appearance of freedom, like the manifestation of principles, coincides with the preforming act. Men are free - as distinguished from their possessing the gift for freedom - as long as they act, neither before nor after; for to be free and to act are the same. (Arendt, 2006a, p. 151)

Arendt's insistence on treating principles as distinguished reasons for action could suggest that she undervalued its more practical goals. In fact, critics accused her theory of a certain detachment from practical public problems. Jon Elster raised the objection that, in Arendt's view, the public action "is not about anything. It is the agonistic display of excellence, or the collective display of solidarity, divorced from decision-making and the exercise of influence on events" (Elster, 1989, p. 128). A similar objection was raised by Martin Jay, who argued that Arendt put forward an idea of action (and politics in general) as "unhampered by all normative or instrumental constraints", such as the struggle for public welfare (Jay, 1978, p. 353). To my mind, these criticisms do not appreciate the subtlety of Arendt's account of action. Although she certainly considered principles as paramount factors behind action, she acknowledged that it could serve as a means for practical goals. This stance can be justified by the following passage:

Action, to be free, must be free from the motive on one side, from its intended goal as a predictable effect on the other. This is not to say that that motives and aims are not important factors in every single act, but they are its determining factors, and action is free to the extent that it is able to transcend them. (Arendt, 2006a, p. 150)

Action is free (spontaneous) to a greater or lesser extent, depending on the degree in which it is guided by principles. I reckon that what Arendt means is that the 'depth' of freedom depends on the extent to which principles outweigh the considerations of individual interests. James T. Knauer has perceptively summarised the essence of Arendt's approach in the following manner: "Her profound insight is that it is the expression of principles of human association in politics that gives meaning to the intentions and goals of the actor, rescuing them from mere instrumentality" (Knauer, 1980, p. 732). 
As will be demonstrated in the subsequent sections, Arendt's concept of action as a spontaneous, principle-driven activity is the definitional aspect of her concept of political freedom. By introducing thus understood action to her account of political freedom, she endowed it with a distinguished significance.

\section{Political Freedom}

Political freedom is usually defined as a capacity of eligible members of the community to participate in exercising power and control over government and administration (e.g. von Hayek, 2011, p. 61). In a similar vein, Arendt claims that "political freedom, generally speaking, means the right 'to be a participator in government', or it means nothing" (Arendt, 2006b, p. 210). This definition does not, however, exhaust the complexity of her account of political freedom, since she also indicated that this right must be realised in a particular manner, i.e. through action. Therefore, Arendt's definition of political freedom is two-dimensional. It encompasses a formally established political sphere of rights and institutions (in this respect, it differs from the public action, which could occur regardless of formal legal guarantees). Arendt is, however, quite explicit that rights and institutions constitute merely the "preliminaries of civilized republic", as opposed to "the very substance of a free republic", i.e. the actual action of the citizens (Arendt, 2006b, p. 210). At this point it is important to note that not every kind of public action is compatible with political freedom. I shall argue that the latter one requires what Arendtian scholars called an 'accommodational' action.

Various authors rightly indicate that Arendt has developed two conflicting accounts of the public action. They labeled them, respectively, as 'agonal' (individualistic) and 'accommodational' (participatory) (cf. Parekh, 1981, p. 177; D’Entrèves, 1994, pp. 97-98; Benhabib, 1997, pp. 4-5). The two approaches rely on different views as to the dominant aim of action and entail two markedly different visions of a political community. According to the agonal variant, developed in The Human Condition, the importance of action stems from its revelatory function. Simply put, according to Arendt, action allows agents to distinguish themselves, i.e. reveal their unique identity. Action thus understood, as Arendt herself admitted, is individualistic and competitive (cf. Arendt, 1998, p. 194; Arendt, 2004, p. 435). It favours self-exposure above other considerations. Bhikhu Parekh has characterised it aptly in the following manner: "A citizen in the agonal view is concerned with his own appearance and immortality and has little regard for the needs of his fellowmen or even the institutions of his society" (Parekh, 1981, p. 178). Such an account of action instrumentalises community, i.e. it is significant insofar as it provides a necessary background against which individuals struggle for distinction.

In her later works, Arendt discarded this markedly individualistic approach and adopted the accommodational (participatory) view on action. This shift of perspective is most apparent in On Revolution, where she emphasised the importance of a cooperative public space and the concern for the common world (rather than a desire for self-exposure) as the 
chief political motivation (cf. Parekh, 1981, p. 177). She wrote that "action, though it may be started in isolation and decided upon by single individuals for very different motives, can be accomplished only by some joint effort in which the motivation of single individuals [...] no longer counts" (Arendt, 2006b, p. 165). It is for axiological reasons that it is the accommodational action rather than the agonal one that constitutes political freedom. Accommodational action enables the creation of the authentic political community based on cooperation and common concern for the public issues. Such a community seems to be a condition for the common conduct of public affairs, which is one of the chief functions of political freedom. To summarise, whereas public action could assume either of the two forms, political freedom relies only on the accommodational action.

I shall now consider the practical aspect of Arendt's account of political freedom, namely the problem of uniting action and participation in government within the confines of political institutions.

\section{Practical Implementation of Arendt's Concept of Political Freedom}

Arendt's discussion of the issue of practical realisation of her ideal of political freedom proceeds in two directions. Firstly, she criticises certain forms of a democratic participation in governance and, secondly, she develops her own bold alternative to the traditional vision of the political order.

The first conclusion which Arendt draws from her definition of political freedom is the exclusion of active suffrage from its realm. In her opinion, voting as a solitary activity fails to meet the criteria of action in that it is incapable of creating a public space; it also does not involve public deliberation or any kind of committed interactions. As Arendt put it, "the voting booth can hardly be called a public space, as it accommodates only one" (Arendt, 2018, p. 507). Along the same lines, expressing opinions in referenda or plebiscites cannot be considered as cases of action (and, thereby, political freedom). It seems, however, that Arendt's characterisation of voting is valid only insofar as citizens are imprudent and indifferent to political matters. I do not see convincing reasons for excluding voting from the realm of political freedom when it is anteceded by a public discussion (in the form of debates with public officials or a deliberative opinion polling). In such case, casting a vote is a formal conclusion of the process of common deliberation and, therefore, can be perceived as one of the aspects of a political action. However, Arendt's objection did not refer only to the procedures of electing representatives, but also to the mere idea of a political representation, which, by its very nature, always constricts the possible scope of participation (cf. Arendt, 2006b, p. 230). While politicians could represent citizens' interest or welfare, they are not capable of representing actions (cf. Arendt, 2006b, p. 260). Therefore,

[...] what we today call democracy is a form of government where the few rule, at least supposedly, in the interest of the many. This government is democratic in that popular welfare and private happiness are its chief goals; but it can be called oligarchic in sense that public happiness and public freedom have again become the privilege of the few. (Arendt, 2006b, p. 261) 
A critical evaluation of a representative democracy encouraged Arendt to propose an alternative system that would be capable of accommodating her particular vision of political freedom based on action. She found its model example in councils that emerged spontaneously during some of the revolutions in the $19^{\text {th }}$ and $20^{\text {th }}$ centuries ${ }^{5}$. She proposed that political system should be composed of numerous councils, starting from the elementary ones that would be functioning in workplaces and neighbourhoods, and ending with the highest council. Their members (coming forward voluntarily) would debate vital public issues and, upon discussion, would relegate their most trusted and committed deputies to higher councils (cf. Arendt, 2006b, p. 270; 2013, p. 104). Thereby, the councils would create "an elite that is chosen by no one but constitutes itself' (Arendt, 2006b, p. 271), which is tantamount to rejecting universal suffrage as understood within a representative democracy. Arendt found councils appealing for two reasons, namely they would provide space for common action and deliberation, and enable to hand over the supervision of public matters to the people who have a particularly strong predilection to public freedom, and put concern for the common world above individual interests (cf. Arendt, 2006b, p. 271).

What should one think about such a proposal? Firstly, it is dubious to assume that the mere procedure of delegating representatives would dismiss the threat of corruption. One could easily imagine the situation when the election to a higher council depends on promising certain favours or advantages. Moreover, it is plausible that the members of the councils would rather delegate the most charismatic and radical, as opposed to public-spirited or reasonable citizens to the higher councils. To put it briefly, I believe that Arendt's faith in public-spiritedness of the deputies in her system of councils is overly optimistic and that the system itself is prone to degeneration just as much as the traditional representative democracy.

Secondly, the question that is even more important from the perspective of the current paper is whether councils are capable of accommodating political freedom to a greater extent than the traditional representative democracies are. The way I see it, it is not necessarily so. Councils might contribute to an increase in the political mobilisation of citizenry, but, more likely, they will enhance the exchange of political elites. People might fully commit themselves to the public matters through the participation in councils, but it is more likely that many of them-perhaps many more than Arendt expected-would choose to exclude themselves from the political community altogether, given the extent of engagement that the system of councils requires. Let me repeat that Arendt's main objection against a representative democracy referred to the fact that it limits the possibility for action. However, as can be seen, councils are likely to face a similar problem. They allow certain groups of citizens to enjoy the participation in government through action, but, since they do not allow a moderate commitment to the public affairs, they make it impossible for those who, for any reason, do not have time or possibility to engage in councils to have any actual influence on politics (even if only by casting a vote).

\footnotetext{
${ }^{5}$ E.g. Soviets of the Russian Revolution or the councils of the Hungarian Revolution of 1956.
} 
Thirdly, it must be noted that important details of Arendt's system of councils are largely underdeveloped in her works. She insisted that councils would supersede political parties, but she did not provide detailed descriptions of their relationship to the executive and legislative power.

From what has been said above, it could be concluded that it is not only a representative democracy that has serious flaws, since the same can be said about the council system. Yet, it would not be honest to ground the criticism of Arendt's theory on this admittedly utopian idea. The council system seems to be more of an illustration of an ideally ordered political community rather than a serious alternative to democracy. ${ }^{6}$ Moreover, these practical considerations seem to be rather inessential from the perspective of the entirety of her thought. The depth and significance of Arendt's theory lies in her insightful anthropological and phenomenological justifications of the public vita activa, i.e. public action. Now, one could enjoy 'anthropological benefits' of public action (i.e. exercising spontaneity, experiencing plurality, and perceiving the world from a variety of perspectives), even though it does not translate into binding political decisions (a formal participation in governance). As Parekh puts it:

Men encounter and acknowledge each other, enter into dialogues and undertake concerted actions in schools, universities, factories, clubs and various other formal and informal contexts. Political participation is not therefore as crucial to human existence as Arendt maintains. As we saw, she sometimes argues as if the political community alone provided public space, and this is obviously not the case. (Parekh, 1981, p. 178)

On the other hand, the participation in governance provides a strong reason for engaging in public action. In other words, the feeling of efficacy and acknowledging that one's engagement can influence the political reality certainly encourages an active commitment to the public matters. Undoubtedly, certain models of democracy accommodate Arendt's exacting ideal of political freedom to greater extent than others. For instance, I believe she would find the participatory democracy more appealing than the representative one, which she associated with the rule by the elite and the decay of public spirit. Yet, my conviction is that discussing Arendt's affinity with the currently debated models of democracy is less relevant than the general message that she tried to convey through her works. In particular, her insightful anthropological and phenomenological observations encourage one to think about political freedom in broad terms. Namely, it does not boil down to undertaking binding political decisions, but is about the decision-making process itself, i.e. the citizens' interactions in the public realm. In other words, common action and deliberation on public issues does not perform a merely instrumental function, but, in addition, it has its own independent value as an important mode of human togetherness.

\footnotetext{
${ }^{6}$ In an interview with Adalbert Reif, Arendt said that "if you ask me now what prospect it [the council system] has of being realized, then I must say to you: Very slight, if at all. And yet perhaps, after all-in the wake of the next revolution" (Arendt, 2013, p. 105).
} 


\section{Final Remarks}

In the present paper, I attempted to analyse the structure of Arendt's concept of political freedom by the means of indicating its various levels, i.e. rudimentary and pre-political freedom as spontaneity, freedom as action, and, finally, freedom as participation in government. This structure is apparently unusual, since she did not define political freedom in a typical manner, i.e. through indicating bundles of legal and political rights that determine the accepted scope of participation in the public affairs. The inherent part of her concept of political freedom is a specific account of how this concept is to be exercised (i.e. through action). This manner of exercising political freedom is simultaneously a vital existential condition of the human life. As I demonstrated, Arendt defined action as the only activity within the hierarchy of the vita activa that truly accommodates two crucial anthropological facts, i.e. human plurality and the capacity to initiate new and unexpected events (the rudimentary freedom of spontaneity). Action has also an axiological dimension, which amounts to the fact that through exercising it one realises public principles, such as solidarity, liberty, equality, or justice (it is worth noting that the Arendtian principles are, in fact, political values). By defining political freedom as one involving action, Arendt endowed it with a particularly strong anthropological and axiological justification. Thereby, she took an explicit standpoint in a debate about the place of political freedom in the hierarchy of democratic values. Through assuming that exercising it is conducive to leading more profoundly human life (i.e. one that realises its fundamental conditions), she provided an argument in favour of its distinguished position. Admittedly, one could enjoy action (and its existential benefits) in various public contexts, participation in government being only one of them. However, a formally established political sphere (which allows one to exert actual influence on public matters) certainly encourages action and, hence, life that realises the fundamental aspects of the human condition.

\section{References}

Arendt, H. (2018). Public Rights and Private Interests: A Response to Charles Frankel. In Thinking Without a Banister: Essays in Understanding 1953-1975 (pp. 506-612). New York, NY: Schocken Books.

Arendt, H. (2013). Thoughts on Politics and Revolution: A Commentary. Interview by Adelbert Rief. In Hannah Arendt: The Last Interview and Other Conversations (pp. 67-105). Brooklyn, NY: Melville House.

Arendt, H. (2006a). What is Freedom? In Between Past and Future (pp. 142-169). New York, NY: Penguin Books.

Arendt, H. (2006b). On Revolution. New York, NY: Penguin Books.

Arendt, H. (2005a). Montesquieu's Revision of the Tradition. In The Promise of Politics (pp. 6369). New York, NY: Schocken Books. 
Arendt, H. (2005b). Introduction into Politics. In The Promise of Politics (pp. 93-200). New York, NY: Schocken Books.

Arendt, H. (2004). Philosophy and Politics, Social Research, 71(3), 427-454.

Arendt, H. (1998). The Human Condition. Chicago, IL: The University of Chicago Press.

Arendt, H. (1996). Love and Saint Augustine. Chicago, IL: The University of Chicago Press.

Arendt, H. (1978). The Life of the Mind (Vol. 2). New York, NY: Harcourt Inc.

Arendt, H. (1958). The Origins of Totalitarianism. Cleveland, OH: Meridian Books.

Augustine. (2002). The City of God Against the Pagans. Cambridge, UK: Cambridge University Press.

Benhabib, S. (1997). The Embattled Public Sphere: Hannah Arendt, Juergen Habermas and Beyond, Theoria: A Journal of Social and Political Theory, No. 90, The Scope and The Limits of Public Reason, 1-24.

Berlin, I. (2000). Two Concepts of Liberty. In The Proper Study of Mankind (pp. 191-242). New York, NY: Farrar, Strauss and Giroux.

Canovan, M. (1992). Hannah Arendt: A Reinterpretation of Her Political Thought. Cambridge, UK: Cambridge University Press.

D’Entrèves, M. P. (1994). The Political Philosophy of Hannah Arendt. London, UK: Routledge.

Elster, J. (1989). The Market and the Forum: Three Varieties of Political Thought. In J. Elster \& A. Hylland (Eds.), Foundations of Social Choice Theory (pp. 103-132). Cambridge, UK: Cambridge University Press.

Jay, M. (1978). Hannah Arendt: Opposing Views, Partisan Review, 45(3), 348-368.

Knauer, J. T. (1980). Motive and Goal in Hannah Arendt's Concept of Political Action, The American Political Science Review, 74(3), 721-733.

Kohn, J. (2000). Freedom: The Priority of the Political. In D. Villa (Ed.), The Cambridge Companion to Hannah Arendt (pp. 113-129). Cambridge, UK: Cambridge University Press.

Parekh, B. (1981). Hannah Arendt and the Search for a New Political Philosophy. London, UK: The Macmillan Press.

Taylor, Ch. (1985). What's Wrong with Negative Liberty. In Philosophy and the Human Sciences. Philosophical Papers (Vol. 2, pp. 211-229). Cambridge, UK: Cambridge University Press.

von Hayek, A. F. (2011). The Constitution of Liberty. Chicago, IL: The University of Chicago Press. Young, I. M. (2000). Inclusion and Democracy. Oxford, UK: Oxford University Press. 